\title{
Pengembangan Perangkat Pembelajaran Matematika Realistik pada Siswa Kelas V SD
}

\author{
Hikmah \\ Dosen Prodi Matematika FMIPA UNSULBAR \\ e-mail: hikmah.ugm@gmail.com
}

\begin{abstract}
Abstrak
Penelitian ini adalah Penelitian Pengembangan yang bertujuan untuk mengembangkan Perangkat Pembelajaran dengan Pendekatan Realistik pada pokok bahasan Pecahan untuk Siswa Kelas V SD, yang meliputi Buku Siswa, Lembar Kegiatan Siswa, Rencana Pelaksanaan Pembelajaran, dan Tes Hasil Belajar. Subjek penelitian ini adalah siswa kelas $V_{A} S D$ Negeri No.2 Kampung Baru Majene sebanyak 25 orang yang terdiri dari 12 orang perempuan dan 13 orang laki-laki. Pengembangan perangkat pembelajaran ini menggunakan model Thiagarajan (Model 4. D) yang terdiri atas 4 (empat) tahap yaitu: pembatasan (define), perancangan (design), pengembangan (develop), dan penyebaran (disseminate). Perangkat pembelajaran matematika dengan pendekatan Realistik yang telah dikembangkan, telah divalidasi oleh pakar dan praktisi dan telah diujicobakan serta mengalami revisi berulang-ulang kali sehingga didapatkan hasil yang valid, efektif, dan praktis.
\end{abstract}

Kata kunci: Penelitian Pengembangan, Pendekatan Realistik, Perangkat Pembelajaran.

\section{PENDAHULUAN}

Ilmu pengetahuan dan teknologi (IPTEK) merupakan bagian dari kehidupan manusia yang berkembang sangat pesat seiring dengan perkembangan zaman. Kenyataan yang terjadi adalah perkembangan ilmu pengetahuan dan teknologi telah membawa perubahan yang sangat signifikan terhadap pelbagai dimensi kehidupan manusia, baik dari segi ekonomi, sosial budaya maupun dunia pendidikan. Akibat dari perkembangan IPTEK itu tentunya timbul suatu masa atau era yang disebut dengan era globalisasi.

Salah satu mata pelajaran yang merefleksikan sifat di atas adalah mata pelajaran matematika, karena matematika merupakan ilmu dasar dan melayani hampir setiap ilmu. Matematika tidak hanya berhubungan dengan bilangan-bilangan serta keterampilan berhitung, melainkan lebih menekankan pada aktivitas dalam dunia rasio yang berkenaan dengan gagasan konsep-konsep abstrak. Begle (1979) menyatakan bahwa sasaran atau obyek penelahaan matematika adalah fakta, konsep, operasi, dan prinsip. Matematika sebagai basic of science atau pengetahuan dasar merupakan suatu alat untuk mengembangkan cara berpikir. Karena itu, matematika sangat diperlukan baik untuk kehidupan sehari-hari maupun dalam menghadapi kemajuan IPTEK sehingga matematika perlu dibekalkan kepada setiap peserta didik.

Saat ini masih banyak keluhan, baik dari orang tua siswa maupun pakar pendidikan matematika, tentang rendahnya kemampuan siswa dalam aplikasi matematika, khususnya penerapan dalam kehidupan sehari-hari. Untuk mengatasi permasalahan di atas perlu digunakan suatu pendekatan yang dapat mendukung proses pembelajaran matematika yang menyenangkan sehingga dapat meningkatkan motivasi siswa dalam belajar matematika. Salah satu pendekatan 
pembelajaran matematika yang tepat untuk melibatkan siswa secara aktif baik fisik, emosi, maupun sosial adalah pendekatan pembelajaran matematika realistik.

Salah satu materi matematika yang banyak digunakan dalam kehidupan sehari-hari adalah pecahan yang diajarkan di SD Kelas V. Penerapan pendekatan pembelajaran matematika realistik dalam pembelajaran matematika di sekolah diharapkan dapat meningkatkan pemahaman dan penguasaan siswa terhadap materi tersebut, karena pembelajaran dengan pendekatan realistik dirancang berawal dari pemecahan masalah yang berada di sekitar siswa dan berbasis pengetahuan yang telah dimiliki siswa. Oleh karena itu, penulis termotivasi melakukan penelitian dengan judul "Pengembangan Perangkat Pembelajaran Matematika dengan Pendekatan Realistik untuk Siswa Kelas V SD".

\section{METODE PENELITIAN}

\section{Jenis Penelitian}

Penelitian ini adalah Penelitian Pengembangan yang bertujuan untuk mengembangkan perangkat pembelajaran matematika yang terdiri dari Buku Siswa, Lembar Kegiatan Siswa, Rencana Pelaksanaan Pembelajaran, dan Tes Hasil Belajar.

\section{Lokasi dan Subjek Penelitian}

Penelitian ini dilaksanakan di SD Negeri No. 2 Kampung Baru Kab. Majene, Sulawesi Barat, dengan subjek penelitian siswa kelas $\mathrm{V}_{\mathrm{A}}$ dengan jumlah siswa sebanyak 25 orang.

\section{Prosedur Penelitian}

Penelitian ini dilaksanakan pada semester genap tahun ajaran 2009/2010 dengan tiga tahap yaitu tahap persiapan, tahap pelaksanaan, dan tahap analisis data.

\section{Tahap Persiapan \\ 2. Tahap Pelaksanaan \\ 3. Tahap Analisis Data}

\section{Pengembangan Perangkat Pembelajaran Matematika}

Pengembangan perangkat pembelajaran matematika yang digunakan mengacu pada model 4 - D Thiagarajan. Model ini terdiri dari 4 tahap, yaitu pendefinisian, perancangan, pengembangan, dan penyebaran.

\section{Pengembangan Instrumen}

Untuk memperoleh informasi tentang aktivitas siswa, aktivitas guru, dan tingkat penguasaan siswa terhadap materi yang telah diajarkan, dikembangkan instrumen-instrumen sebagai berikut:

\section{Lembar Pengamatan Aktivitas Siswa \\ 2. Lembar Pengamatan Aktivitas Guru \\ 3. Respons Siswa terhadap Kegiatan Pembelajaran \\ 4. Tes Hasil Belajar}

\section{Validasi dan Analisis}

Data yang telah dikumpulkan dengan menggunakan instrumen-instrumen seperti yang telah disebutkan pada bagian E, selanjutnya dianalisis secara kuantitatif untuk menentukan kevalidan, 
JURNAL SAINTIFIK VOL.3 NO.1, JANUARI 2017

kepraktisan, dan keefektifan. Data yang diperoleh dari hasil validasi oleh para ahli dianalisis untuk menjelaskan kevalidan dan kelayakan penggunaan perangkat pembelajaran yang telah dibuat. Adapun data hasil uji coba di kelas digunakan untuk menjelaskan kepraktisan dan keefektifan.

Berikut ini dikemukakan tentang analisis data kevalidan, kepraktisan, dan keefektifan.

1. Analisis Data Kevalidan Perangkat Pembelajaran Matematika Realistik

2. Analisis Data Keefektifan Perangkat Pembelajaran Matematika Realistik

Kegiatan analisis data terhadap ketiga komponen itu adalah sebagai berikut:

a. Analisis Data Hasil Belajar Siswa

b. Analisis Data Aktivitas Siswa

c. Analisis Respons Siswa

3. Analisis Data Kepraktisan Perangkat Pembelajaran Matematika Realistik.

Data kepraktisan perangkat pembelajaran matematika realistik terdiri dari dua bagian, yaitu (1) pendapat dari para ahli dan praktisi yang menyatakan bahwa Pembelajaran Matematika Realistik ini praktis dan (2) data dari kemampuan guru dalam mengelola pembelajaran realistik.

\section{HASIL DAN PEMBAHASAN}

\section{Hasil Penelitian}

\section{Deskripsi Tahap Pembatasan}

a. Analisis kurikulum

Pada tingkat Sekolah Dasar, Kurikulum Tingkat Satuan Pendidikan yang disusun merupakan pengetahuan, keterampilan, pengenalan, dan pemahaman berfikir deduktif yang dapat mengarahkan kepada kecermatan serta sistematika berfikir dan bertindak. Pada SD Negeri No. 2 Kampung Baru Kab. Majene materi yang diajukan pada proses pembelajaran sesuai dengan kurikulum yang beraku yaitu Kurikulum Tingkat Satuan Pendidikan.

b. Analisis siswa

Pada analisis siswa tentang karakteristik siswa yang diberikan sesuai dengan karakteristik matematika realistik yang meliputi latar belakang kemampuan akademik siswa kelas V SD Negeri No.2 Kampng Baru Kab. Majene dan perkembangan kognitif siswa. Walaupun demikian guru masih perlu mengingatkan kembali materi tersebut pada awal pertemuan. Bahasa yang digunakan siswa dalam kehidupan seharihari sebagian besar menggunakan Bahasa Indonesia, dan bahasa yang digunakan dalam proses pembelajaran adalah Bahasa Indonesia.

c. Analisis konsep

Konsep-konsep yang dianalisis dalam penelitian ini merupakan konsep dalam materi pokok bahasan Pecahan untuk SD Kelas V dengan mengacu kepada kurikulum tingkat satuan pendidikan (KTSP).

d. Analisis Tugas

Analisis tugas dengan materi pecahan diarahkan pada pengalaman belajar siswa, sehingga tujuan pembelajaran dapat tercapai

e. Spesifikasi Tujuan Pembelajaran

Adapun tujuan pembelajaran yang ingin dicapai dari proses pembelajaran, yaitu:

1. Siswa dapat mengetahui makna persen.

2. Siswa dapat mengubah bentuk pecahan ke bentuk persen dan desimal serta sebaliknya. 
3. Siswa dapat membandingkan dua buah pecahan dengan menggunakan garis bilangan.

4. Siswa dapat menjumlahkan dan mengurangkan bilangan pecahan baik yang berpenyebut sama maupun yang tidak sama.

\section{Deskripsi Tahap Rancangan}
a. Penyusunan tes
b. Pemilihan media
c. Pemilihan format
d. Rancangan awal

4. Deskripsi Tahap Pengembangan

a. Penilaian ahli

Tabel 4.10 Rangkuman Hasil Validasi Perangkat Pembelajaran

\begin{tabular}{||l|c|c||}
\hline \multicolumn{1}{|c|}{ PERANGKAT } & Skor Rata-rata Penilaian & Status \\
\hline Buku Siswa & 4,5 & Sangat Valid \\
\hline Lembar Kerja Siswa & 4,4 & Valid \\
\hline Rencana Pelaksanaan Pembelajaran & 4,4 & Valid \\
\hline Tes Hasil Belajar & 4,5 & Sangat valid \\
\hline \hline
\end{tabular}

\section{B. Hasil ujicoba}

Sebagaimana yang telah disebutkan sebelumnya bahwa perangkat pembelajaran hasil revisi berdasarkan masukan atau saran dari para validator yang selanjutnya diujicobakan pada siswa kelas $\mathrm{V}_{\mathrm{A}}$ SD Negeri No. 2 Kampung Baru, Kab. Majene.

\section{Analisis Deskriptif Hasil Penelitian}

Berdasarkan hasil ujicoba perangkat pembelajaran yang meliputi BS, LKS, RPP, dan THB diperoleh data hasil THB, data hasil pengamatan aktivitas siswa, respon siswa terhadap kegiatan dan perangkat pembelajaran matematika dengan pendekatan realistik, dan data hasil pengamatan aktivitas guru. Data-data inilah yang digunakan untuk mengetahui kepraktisan dan keefektifan perangkat pembelajaran matematika dengan pendekatan realistik. Hasil analisis masing-masing data sebagai berikut:

1. Hasil Tes Belajar Siswa

Secara kuantitatif penguasaan matematika setelah diberi tindakan pada THB dapat dilihat pada tabel 4.14. 
JURNAL SAINTIFIK VOL.3 NO.1, JANUARI 2017

Tabel 4.14 Statistik Skor Hasil Belajar Matematika Siswa Kelas V SD Negeri No. 2 Kampung Baru, Kab. Majene

\begin{tabular}{||c||c||c||}
\hline \hline No & Statistik & Nilai Statistik \\
\hline \hline 1 & Subjek penelitian & 25 \\
\hline 2 & Skor ideal & 100 \\
\hline 3 & Rata-rata & 75,36 \\
\hline 4 & Standar deviasi & 15,20 \\
\hline 5 & Variansi & 231,16 \\
\hline 6 & Rentang skor & 54 \\
\hline 7 & Skor maksimum & 100 \\
\hline 8 & Skor minimum & 46 \\
\hline 9 & Siswa yang tuntas & 21 \\
\hline 10 & Siswa yang tidak tuntas & 4 \\
\hline
\end{tabular}

Tabel di atas menunjukkan bahwa skor hasil belajar siswa Kelas $V_{A}$ SD Negeri No. 2 Kampung Baru Majene terhadap pelajaran matematika diperoleh skor rata-rata 75,36 dengan standar deviasi 15,20. Skor minimum yang diperoleh siswa adalah 46 dari skor terendah yang mungkin dicapai oleh siswa yaitu 0 , dan skor maksimum yang diperoleh siswa adalah 100 dari skor ideal yang mungkin dicapai oleh siswa yaitu 100 dengan rentang skor 54 .

Jika skor hasil belajar matematika siswa tersebut dikelompokkan dalam 5 kategori, maka diperoleh distribusi frekuensi seperti ditunjukkan pada

tabel 4.15.

Tabel 4.15 Distribusi frekuensi dan persentase skor hasil belajar matematika siswa Kelas V SD Negeri No. 2 Kampung Baru, Kab. Majene

\begin{tabular}{|c|c|c|c|c|c|}
\hline No & \multicolumn{2}{|c|}{ Nilai } & Kategori & Frekuensi & Persentase \\
\hline 1 & \multicolumn{2}{|c|}{$0-34$} & Sangat Rendah & 0 & $0 \%$ \\
\hline 2 & \multicolumn{2}{|c|}{$35-54$} & Rendah & 2 & $8 \%$ \\
\hline \multirow{2}{*}{3} & \multirow{2}{*}{$55-64$} & $55-59$ & \multirow{2}{*}{ Sedang } & 2 & $8 \%$ \\
\hline & & $60-64$ & & 2 & $8 \%$ \\
\hline 4 & \multicolumn{2}{|c|}{$65-84$} & Tinggi & 11 & $44 \%$ \\
\hline 5 & \multicolumn{2}{|c|}{$85-100$} & Sangat Tinggi & 8 & $32 \%$ \\
\hline
\end{tabular}

Tabel di atas menunjukkan bahwa dari 25 siswa yang mengikuti tes, tidak terdapat siswa yang masuk dalam kategori sangat rendah. Terdapat 2 orang siswa (8\%) pada kategori rendah, sedangkan siswa yang berada pada kategori sedang sebanyak 4 orang (16\%). Siswa yang berada pada kategori tinggi ada sebanyak 11 orang (44\%), sedangkan siswa yang termasuk kategori sangat tinggi sebanyak 8 orang (32\%). Dengan demikian, dapat disimpulkan bahwa skor rata-rata hasil belajar matematika siswa berada dalam kategori tinggi. 
Tabel di atas juga menunjukkan bahwa banyaknya siswa yang tidak tuntas belajar yaitu siswa yang memperoleh skor $0-59$ sebanyak 4 orang dari 25 siswa atau sekitar $16 \%$. Adapun siswa yang tuntas belajar yaitu memperoleh skor 60 - 100 sebanyak 21 orang dari 25 siswa atau sekitar $84 \%$. Data ini menunjukkan bahwa ketuntasan klasikal tercapai.

2. Respon siswa terhadap kegiatan pembelajaran

a. Respon siswa tentang pelajaran matematika

Dari hasil observasi diketahui bahwa 14 dari 25 siswa (56\%) merasa senang dengan pelajaran matematika. Dari hasil observasi juga diketahui bahwa 3 dari 25 siswa (12\%) menyatakan bahwa matematika itu gampang dan menyenangkan jika disajikan dengan cara singkat dan jelas. 5 dari 25 (20\%) siswa merasa bahwa matematika adalah pelajaran yang sulit. Namun dengan adanya pembelajaran dengan menggunakan pendekatan realistik mereka merasa belajar matematika menyenangkan dan lebih mudah. Selain itu, 3 dari 25 siswa (12\%) menyatakan bahwa matematika itu sulit tapi menantang.

b. Respons siswa tentang buku siswa dan LKS

Dari hasil observasi diketahui bahwa 20 dari 25 siswa (80\%) merasa senang dengan buku siswa dan LKS yang digunakan.

c. Respons siswa tentang pembelajaran dengan menggunakan pendekatan realistik Semua siswa di kelas $\mathrm{V}_{\mathrm{A}}(100 \%)$ senang dengan pembelajaran dengan menggunakan pendekatan realistik.

Berdasarkan kriteria keefektifan yang telah dibahas, maka dapat disimpulkan bahwa perangkat pembelajaran matematika dengan pendekatan realistik bersifat efektif, dimana semua komponen keefektifan perangkat terpenuhi dan komponen (1) yaitu ketuntasan klasikal yang menjadi syarat utama terpenuhi. Selain itu, berdasarkan kriteria kepraktisan yang juga telah dibahas, maka dapat disimpulkan pula bahwa perangkat pembelajaran matematika dengan pendekatan realistik bersifat praktis, dimana semua komponen kepraktisan perangkat terpenuhi.

\section{KESIMPULAN}

Berdasarkan pembahasan hasil penelitian dan ujicoba terbatas terhadap siswa kelas $\mathrm{V}_{\mathrm{A}} \mathrm{SD}$ Negeri No. 2 Kampung Baru, Majene, dapat diambil kesimpulan sebagai berikut:

1) Perangkat pembelajaran matematika realistik yang dikembangkan pada pokok bahasan Pecahan dalam penelitian ini adalah Buku Siswa, Lembar Kegiatan Siswa, dan Rencana Pelaksanaan Pembelajaran, dan Tes Hasil Belajar.

2) Pengembangan perangkat ini menggunakan model Thiagarajan atau 4-D (Define, Design, Develop, dan Disseminate) yang meliputi empat tahap yaitu tahap pendefinisian, tahap perancangan, tahap pengembangan, dan tahap penyebaran, namun pada penelitian ini tahap penyebaran belum dapat dilaksanakan karena pelaksanaannya hanya berupa ujicoba terbatas saja.

3) Setelah dilakukan validasi dan revisi sebanyak 2 kali, perangkat pembelajaran yang meliputi Buku Siswa, LKS, RPP, dan THB ini valid dan layak untuk digunakan berdasarkan hasil penilaian para ahli.

4) Dari hasil ujicoba diketahui bahwa perangkat pembelajaran dengan pendekatan realistik bersifat efektif dan praktis, dilihat dari pendapat para ahli dan praktisi, 


\section{JURNAL SAINTIFIK VOL.3 NO.1, JANUARI 2017}

ketuntasan klasikal tercapai, Siswa lebih aktif dalam proses pembelajaran, guru mampu mengelola pembelajaran, serta pada umumnya siswa memberikan respon yang positif terhadap perangkat pembelajaran yang digunakan.

\section{DAFTAR PUSTAKA}

Anonim. 2005. Metode Penelitian dalam Pendidikan Matematika Tinjauan pada: Penelitian Tindakan Kelas \& Pengembangan Perangkat Pembelajaran. Disajikan pada Workshop Penelitian Pengembangan Matematika dan Pembelajarannya. Makassar: Himpunan Mahasiswa Matematika. FMIPA. UNM.

Dimyati dan Mudjiono.1994. Belajar dan Pembelajaran. Jakarta : Departemen Pendidikan dan Kebudayaan.

Gravemeijer, Falmer Press, 1994. Developing Realistics Mathematics Education. London: Freudenthal Institute.

Hamalik, O. 2005. Kurikulum dan Pembelajaran. Jakarta: Bumi Aksara.

Jumriati. 2006. Pengembangan Perangkat Pembelajaran Matematika Berbasis Contextual Teaching and Learning. Skripsi. Makassar FMIPA UNM.

Soedjadi. 2000. Nuansa Kurikulum Matematika Sekolah. Price,J., "Presidents Report : Bulding Bridges of Mathematical Understanding for All Children"., Dalam Journal for Research in Mathematics Education. Vol.27. No.5 November 1996, hal. 603-608.

Subaer. 2004.Research and Development $(R \& D)$ Design. Makalah yang disampaikan pada seminar nasional Research dan Development. Tidak diterbitkan.

Suherman, Erman. Dkk. 2003. Strategi Pembelajaran Matematika Kontemporer. Bandung : JICA.

Sumanto Y.D. Dkk. 2008. Gemar Matematika 5. Jakarta: Pusat Perbukuan Departemen Pendidikan Nasional.

Syahrianti, Sitti, 2004. Peningkatan Hasil Belajar Matematika Melalui Pendekatan Realistik pada Siswa Kelas II SLTP Negeri 4 Makassar. Skripsi. Tidak diterbitkan: FMIPA UNM.

Teguh, Purwantari. Dkk. 2006. Memahami dan Berlatih Matematika. Jakarta: Bumi Aksara.

Upu, Hamzah, 2004. Mensinergikan Pendidikan Matematika dengan Bidang Lain. Makassar:

Pustaka Ramadhan. 